\title{
Note
}

Brett D. Hirsch

\section{Hornpipes and Disordered Dancing in The Late Lancashire Witches: A Reel Crux?}

A memorable scene in act 3 of Thomas Heywood and Richard Brome's The Late Lancashire Witches (first performed and published 1634) plays out the bewitching of a wedding party and the comedy that ensues. As the partygoers 'beginne to daunce' to 'Selengers round', the musicians instead 'play another tune' and 'then fall into many' (F4r). ${ }^{1}$ With both diabolical intervention ('the Divell ride o' your Fiddlestickes') and alcoholic excess ('drunken rogues') suspected as causes of the confusion, Doughty instructs the musicians to 'begin againe soberly' with another tune, 'The Beginning of the World', but the result is more chaos, with 'Every one [playing] a seuerall tune' at once (F4r). The music then suddenly ceases altogether, despite the fiddlers claiming that they play 'as loud as [they] can possibly', before smashing their instruments in frustration (F4v).

With neither fiddles nor any doubt left that witchcraft is to blame, Whetstone calls in a piper as a substitute since it is well known that 'no Witchcraft can take hold of a Lancashire Bag-pipe, for itselfe is able to charme the Divell' (F4v). Instructed to play 'a lusty Horne-pipe', the piper plays with 'all [joining] into the daunce', both 'young and old' (G1r). The stage directions call for the bride and bridegroom, Lawrence and Parnell, to 'reele in the daunce' (G1r). At the end of the dance, which concludes the scene, the piper vanishes 'no bodie knowes how' along with Moll Spencer, one of the dancers who, unbeknownst to the rest of the party, is the witch responsible (G1r).

Brett D. Hirsch (brett.hirsch@uwa.edu.au) is university postdoctoral research fellow at The University of Western Australia. 
All three previous editors of The Late Lancashire Witches have overlooked a potential crux in the sense of the word 'reel' in this scene. As a verb, reel may mean 'To whirl or wheel around; to go with a whirling or rolling motion; to spin or appear to spin', 2 'To wind thread, yarn, etc. on to a reel as part of the process of production', ${ }^{3}$ or 'to dance a reel; to perform the travelling or looping figure in such a dance'. ${ }^{4}$ The two most recent editions, Helen Ostovich's 2010 edition for Richard Brome Online and Gabriel Egan's 2002 edition for the Globe Quartos, do not comment on the passage at all. ${ }^{5}$ Laird $\mathrm{H}$. Barber's 1979 edition for the Garland Renaissance Drama series recognizes that Moll's witchcraft 'has already thrown the musicians into disorder' and 'now disrupts the dance - specifically the dancing of the bride and groom', but does not elaborate on how this episode is staged. ${ }^{6}$ The word reel and its potential have similarly escaped mention in what little criticism of the play is extant.

Most likely, reel is operates here as a verb in the first sense of going about in a 'whirling or rolling motion'. Alan C. Dessen and Leslie Thomson have recorded a number of instances in stage directions from the drama of the period in which the term reel describes 'a drunken whirling or staggering action' or 'an unsteady movement not linked to drunkenness', and list The Late Lancashire Witches as an example of the latter.' Outside of stage directions, a roughly contemporaneous example appears in James Shirley's The Lady of Pleasure, licensed for the stage in 1635, in which Alexander berates Celestina in the following dialogue:

You doe not sing so well as I imagind,

Nor dance, you reele in your coranto, and pinch

Your petticoate too hard, y'have no good eare

Toth' musicke, and incline too much one shoulder,

As you were dancing on the rope, and falling.

$(\mathrm{F} 4 \mathrm{v})^{8}$

The coranto is a dance that is 'delightfully simple and light, producing the effect of a sprightly skipping motion.' An earlier example is William Shakespeare's Hamlet, in which Horatio is told, 'The King doth wake to night, and takes his rouse, / Keeps wassels and the swaggering vpspring reeles' $(2 \mathrm{O} 1 \mathrm{r}$; TLN 612-13), ${ }^{10}$ that is, he drunkenly swaggers whilst dancing the Hüpfauf (literally 'upspring' or 'jump up'), a lively German dance. ${ }^{11}$ Clearly The Late Lancashire Witches is not unique in the drama of the period for its use of the word reel to suggest disordered, staggering, or otherwise unmannerly dancing. 
Another possible, less likely (but not impossible) reading, however, interprets reel as a reference to the duple time Scottish folk dance of the same name. Although earlier references in Scottish texts exist, according to J.F. and T.M. Flett, 'It is not until about 1583 that we find the word reel (or rather reill) definitely used to mean a dance' in Scotland, and then the 'only other reference to a Reel in the sixteenth century occurs in the trial of the North Berwick witches in 1591'. ${ }^{2}$ A pamphlet, Newes from Scotland, published in London soon after the trial, offered English readers a sensational account of this diabolic conspiracy to kill James VI by witchcraft and his direct involvement in its detection. ${ }^{13}$ The pamphlet reports the confession of Agnes Tompson, one of the accused witches, as follows:

Item, the saide Agnis Tompson was after brought againe before the kings Maiestie and his Counsell, and being examined of the meetings and detestable dealings of those witches, she confessed that vpon the night of Allhollon Euenlast, she was accompanied aswell with the persons aforesaide, as also with a great many other witches, to the number of two hundreth: and that all they together went by Sea each one in a Riddle or Ciue, and went in the same very substantially with flaggons of wine making merrie and drinking by the waye in the same Riddles or Ciues, to the kerke of North Barrick in Lowthian, and that after they had landed, tooke handes on the land and daunced this reill or short daunce, singing all with one voice. At which time she confessed, that this Geilles Duncane did goe before them playing this reill or daunce vpon a small Trump, called a Iewes Trump, vntill they entred into the kerk of north Barrick. ${ }^{14}$

The king, 'in wonderful admiration' of such testimony, sent for Gilles Duncan, 'who vpon the like Trump did playe the said daunce before the kings Maiestie, who in respect of the strangenes of these matters, tooke great delight to bee present at their examinations. ${ }^{15}$ As Flett and Flett have noted, although the pattern of the reel could take on a number of shapes - couples dancing a figure of eight with or without an added loop, a pair of intersecting ovals, a square with looped corners, a circle - the pamphlet's description of the witches having 'tooke handes' and the reel as a 'short daunce' suggests a dance in a ring, in 'a contrast with the long line dance.' ${ }^{16}$ In her study of music in seventeenth-century English witchcraft plays, Amanda Eubanks Winkler confirms this finding. Winkler argues that the reel was 'frequently performed in a circle' and was therefore linked to the common depiction of witches dancing in rounds. ${ }^{17}$ A woodcut from Nathaniel Crouch's The Kingdom of 


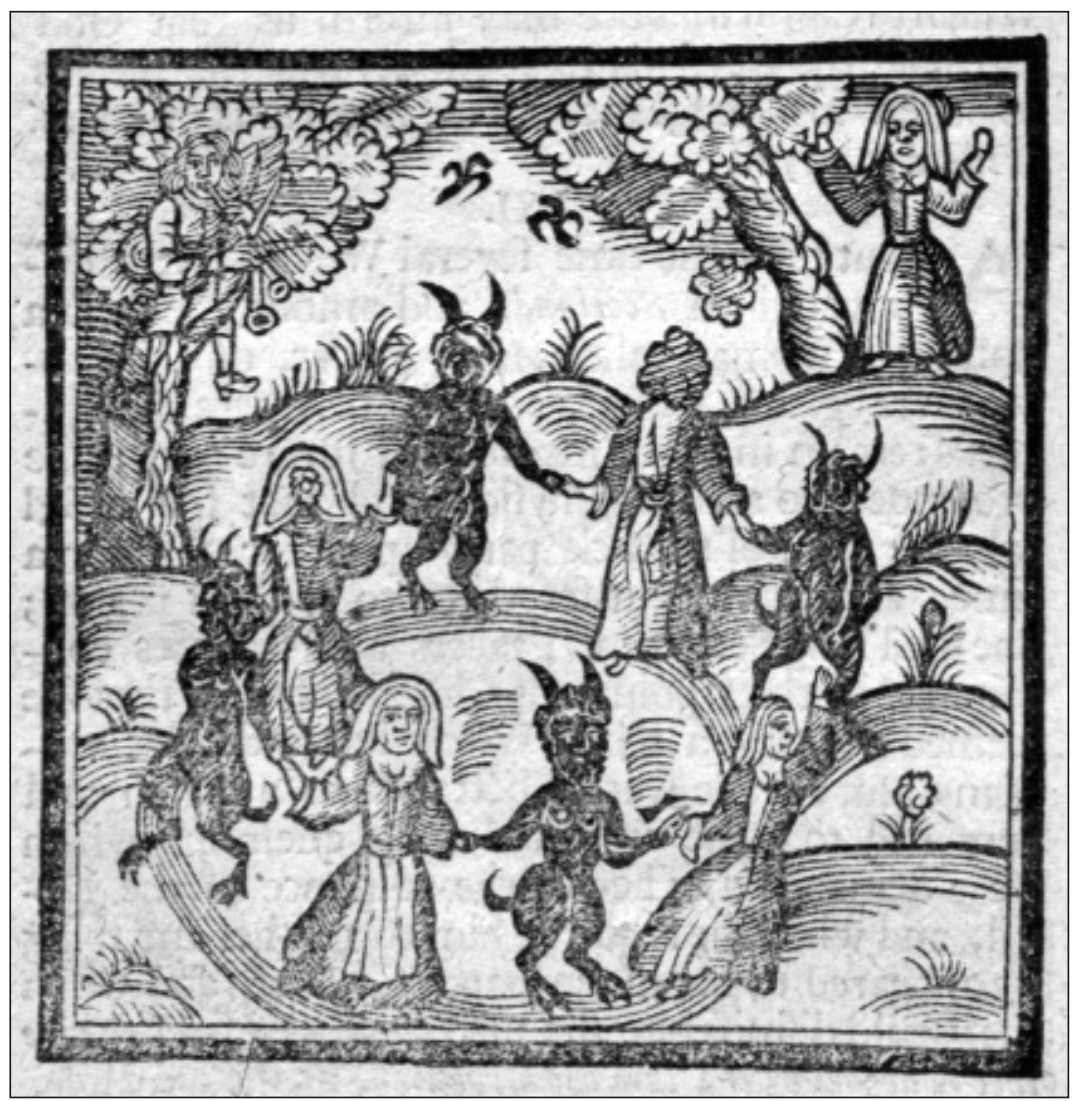

Figure 1. R.B. [i.e. Nathaniel Crouch], The Kingdom of Darkness (London, 1688; Wing C7342), F11v. The same woodcut appears on sigs. C12r and F5r. Courtesy of the Division of Rare and Manuscript Collections, Cornell University Library.

Darkness (London, 1688) provides a pertinent example in which couples of witches and devils dance in a round to bagpipe music (Figure 1).

News from Scotland tantalizingly links witchcraft to the dancing of reels (whatever their precise shape may have been) for an English readership, but it is unique: no other references to the reel as a dance form appear in print in England during the sixteenth and seventeenth centuries. ${ }^{18}$ This paucity of evidence, however, did not deter earlier Shakespeare editors from suggesting a reading of the word reel as a dance when Enobarbus calls on his fellow carousers to 'Drinke thou: encrease the Reeles' in Antony and Cleopatra 
(2X6r; TLN 1443). As the New Variorum Shakespeare records, George Steevens commented that 'reel was not, in our author's time, employed to signify a dance or revel', to which Francis Douce replied, 'In all events Steevens has erred', citing Newes from Scotland as evidence of contemporary use. ${ }^{19}$ Subsequent editions have more or less ignored Douce's suggestion. For example, recent editors of the play variously gloss reels as 'whirls', 20 'whirling movements', ${ }^{21}$ 'revels' or 'reeling and whirling from drunkenness', ${ }^{22}$ and 'revels' or 'staggering motions', ${ }^{23}$ rendering the line, 'Drink up, and you will (1) increase the number of those who are reeling or staggering, (2) increase the revels. ${ }^{24}$ Michael Neill, in his edition for the Oxford Shakespeare, is the only recent editor to gloss the word to mean 'dancing' as well as 'whirling or staggering movement' and 'revels.'. ${ }^{25}$

It remains open to debate whether Neill's expansive gloss in Antony and Cleopatra is too generous, given such limited English evidence. ${ }^{26}$ Nonetheless, a valid reading of the word reel as a dance in The Late Lancashire Witches is possible. Such a reading is not only congruent with the witchcraft theme so central to the play and to this scene in particular, but it also adds a further element to the comedy. When the rest of the wedding party are dancing a hornpipe, what if the bewitched bride and bridegroom instead 'reele in the daunce' (G1r) - that is, dance a reel, an entirely different dance?

The precise nature of this difference requires further investigation. Although the $O E D$ defines the hornpipe as 'a dance of a lively and vigorous character, usually performed by a single person, orig. to the accompaniment of the wind instrument [for which it is named], and specially associated with the merrymaking of sailors', ${ }^{27}$ its history and development, as Martha Curti has shown, was more varied:

The mention of the hornpipe today invariably brings associations of sailors dancing singly or in pairs, facing one another, and of fast music in duple metre ... Originally, however, the hornpipe was in triple metre and was danced, not by sailors, but by country people, and not as a solo dance for men but as a round dance for couples. ${ }^{28}$

As with other dances of folk origin, the 'triple-metre hornpipe gradually found its way into upper-class society during the sixteenth and seventeenth centuries and appears in stylized form in many dance suites of the period'. ${ }^{29}$ Whether through processes of cultural appropriation and gentrification as described by Curti, or as the result of what J.S. Bratton has characterized 
as the hornpipe's 'haziness of definition and competing claims about [its] origins, ${ }^{30}$ by the time The Late Lancashire Witches was first staged the term could refer variously to a round dance for couples, a solo step dance, or a stylized upper-class group dance. ${ }^{31}$

The drama of the period provides examples of the various dance forms of the hornpipe. ${ }^{32}$ When Dog bewitches Anne Ratcliffe in act 4 of The Witch of Edmonton (first performed 1621, published 1658) and complains, 'There's a Lancashire Horn-pipe in my throat: hark how it tickles it, with Doodle, Doodle, Doodle, Doodle', her call to 'Hands, hands; hold hands, and dance a-round, a-round, a-round' (G2r) ${ }^{33}$ suggests the round country dance for couples, and not the stylized dance of the gentry — 'longways for as many as will' 34 — or the solo step dance later associated with sailors. ${ }^{35}$ By contrast, the devils Astaroth and Belchar offer 'a horne-pipe [to] treade' in act 5 of The Devil's Charter (first performed 1606, published 1607) but the stage directions indicate that 'They dance an antick', that is, presumably, a more stylized dance appropriate for an antimasque (L2v). ${ }^{36}$ In The Counterfeit Bridegroom (published 1677), a Restoration adaptation of Thomas Middleton's No Wit, No Help Like a Woman's attributed variously to Thomas Betterton and Aphra Behn, Sir Oliver Santlow dances a Lancashire hornpipe now 'quite out of fashion' - on his own in act 5, albeit after much revelling and carousing $(\mathrm{H} 1 \mathrm{v}) .{ }^{37}$ Whether the comedy of this particular scene arises from the dance being passé, its performance by a drunk without a partner, its performance by a member of an elite social rank, or any combination of these is unclear. 38

Given the setting of a country wedding in The Late Lancashire Witches, the hornpipe referred to in the scene is likely a round dance for couples. ${ }^{39}$ Contemporary descriptions of performances of the dance at weddings and other social gatherings corroborate this assumption. A sixteenth-century ballad attributed to John Wallys, 'Our Jocky sale have our Jenny', offers a poetic account of a hornpipe danced at a wedding party. After eating his fill of 'swynes flesshe', 'sarder and sodden corne', the groom asks that 'the pypar pype up sone, / For, be our Lord, I wyll go dance'. As the piper begins to play a 'horn pype', the leader calls the dancers to perform its various steps:

Halfe torne, Jone, haffe nowe, Jocke!

Well dansyde, be sent Dennye!

And he that breakys the firste strocke,

Sall gyve the pypar a pennye. 
In with fut, Robsone! owt with fut, Byllynge!

Here wyll be good daunsyng belyve;

Torn rownde, Robyne! kepe trace, Wylkyne!

Mak churchye pege behynde. ${ }^{40}$

A further example is Henry Spelman's first-hand account of Virginia in 1609-10, in which he likens the traditional dancing of the native Powhatan to the dancing of hornpipes in the Derbyshire countryside: 'when they meet at feasts or otherwise they vse sprorts [sic] much like to ours heare in England as ther daunsinge, which is like our darbysher Hornepipe a man first and then a woman, and so through them all, hanging all in a round'. ${ }^{41}$

Even if the dance form of the hornpipe was various by the seventeenth century, its musical accompaniment appears to have remained consistent. Musicians played the hornpipe in triple metre (i.e., in 3/2, 6/4, or 12/8 time) until the eighteenth century, at which point it transformed into duple metre (i.e., in $2 / 2,4 / 4$, or $8 / 8$ time). ${ }^{42}$ George Emmerson has noted that this preeighteenth century form 'was a peculiar syncopated limping-gait of a tune in triple-time ... a rhythm which Purcell and Handel regarded as peculiarly English. ${ }^{43}$ In the most recent (and most thorough) musicological study of the hornpipe, John M. Ward argues that before its transformation by Purcell and his contemporaries, 'little changed formally from the time of Henry VIII, and no doubt earlier. ${ }^{44}$ Whatever uncertainties remain about how the hornpipe was danced in The Late Lancashire Witches, according to Ward, 'we can be relatively certain it was in triple time, implied a double-tonic ground, and included the sort of "rhyming" bars characteristic of the genre for at least two centuries. ${ }^{45}$

As a Scottish folk dance in duple time, the reel stands in stark contrast to the triple time hornpipe, a 'uniquely English dance' that 'centred in Derbyshire, Lancashire, and Nottingham. ${ }^{46}$ If a seventeenth-century English audience could distinguish between the two dances in The Late Lancashire Witches, the action when the bride and bridegroom 'reele in the daunce' that is, attempt to perform a Scottish duple metre dance to syncopated, triple metre, English hornpipe music - must have been comedic in its dissonance and futility. 
I46 Brett D. Hirsch

\section{Notes}

1 Thomas Heywood and Richard Brome, The Late Lancashire Witches (London, 1634; STC 13373). Unless otherwise noted in the text, all references are to this edition, cited by signature in parentheses.

2 OED Online, s.v. 'reel, v.1, 1.a', last modified March 2013.

3 Ibid, s.v. 'reel, v.2, 1.a', last modified March 2013.

4 Ibid, s.v. 'reel, v.3', last modified March 2013.

5 Helen Ostovich (ed.), The Late Lancashire Witches, Richard Brome Online (Sheffield, 2010), http://www.hrionline.ac.uk/brome/; Gabriel Egan (ed.), The Witches of Lancashire (London, 2002).

6 Laird H. Barber (ed.), An Edition of The Late Lancashire Witches (New York, 1976), $178 \mathrm{a}$.

7 Alan C. Dessen and Leslie Thomson, A Dictionary of Stage Directions in English Drama, 1580-1642 (Cambridge, 1999), 178 (emphasis original).

8 James Shirley, The Lady of Pleasure (London, 1637; sтc 22448).

9 Mabel Dolmetsch, Dances of English and France from 1450 to 1600 (London, 1949), 133.

10 William Shakespeare, Mr. William Shakespeares Comedies, Histories, \& Tragedies (London, 1623; sтс 22273). All subsequent references to Shakespeare are to the First Folio, by signature and through line number.

11 Editors since Steevens have typically glossed the word upspring with reference to The Tragedy of Alphonsus, Emperour of Germany (London, 1654; Wing C1952), attributed to George Chapman, in which Bohemia explains, 'We Germans have no changes in our dances, / An Almain and an upspring that is all' (F1r).

12 J.F. and T.M. Flett, 'The History of the Scottish Reel as a Dance-Form', Scottish Studies 16.2 (1972), 93.

13 Newes from Scotland, Declaring the Damnable life and death of Doctor Fian, a notable Sorcerer, who was burned at Edenbrough in Ianuary last (London, 1591?; STC 10842.3). Scholars have attributed authorship of the pamphlet to James Carmichael, minister of Haddington, who assisted in the interrogations.

14 Ibid, A3r-v.

15 Ibid, A3v.

16 Flett and Flett, 'The History of the Scottish Reel as a Dance-Form', 94.

17 Amanda Eubanks Winkler, O let us howle some heavy note: Music for Witches, the Melancholic, and the Mad on the Seventeenth-Century English Stage (Bloomington, 2006), 29-30. 
18 Searches for the term on the LEME, LION, and EEBO-TCP databases confirm this. While these databases are not yet exhaustive, they are representative.

19 Horace Howard Furness (ed.), The Tragedie of Anthonie and Cleopatra (Philadelphia, 1907), 15.163n111.

20 A.R. Braunmuller (ed.), Antony and Cleopatra (Harmondsworth, 1999), 57n92.

21 Barbara A. Mowat and Paul Werstine (eds.), Antony and Cleopatra (New York, 1999), 106n109.

22 David Quint (ed.), Antony and Cleopatra (New York, 2008), 55n92.

23 John Wilders (ed.), Antony and Cleopatra (London, 1995), 168n94; Jonathan Bate and Eric Rasmussen (eds.), Antony and Cleopatra (New York, 2009), 67n101.

24 David M. Bevington (ed.), Antony and Cleopatra 2nd edn (Cambridge, 2005), 159 n 87.

25 Michael Neill (ed.), Antony and Cleopatra (Oxford, 1994), 216 n91.

26 Seminal works on dancing in the drama of the period, including Charles Read Baskervill's The Elizabethan Jig and Related Song Drama (Chicago, 1929), Alan Brissenden's Shakespeare and the Dance (London, 1981), and Barbara Ravelhofer's The Early Stuart Masque: Dance, Costume, and Music (Oxford, 2006), do not make any reference to the reel at all.

27 OED Online, s.v. 'hornpipe, n.2', last modified March 2013.

28 Martha Curti, 'The Hornpipe in the Seventeenth Century', The Music Review 40.1 (1979), 14.

29 Ibid, 14.

30 J.S. Bratton, 'Dancing a Hornpipe in Fetters', Folk Music Journal 6.1 (1990), 3.

31 Curti, 'The Hornpipe in the Seventeenth Century', 14-5.

32 The surprisingly high proportion of references to hornpipes and other dances in plays of the period dealing with witchcraft, magic, and devils deserves fuller scholarly treatment. In the first instance, the interested reader is directed to Diane Purkiss, The Witch in History: Early Modern and Twentieth-Century Representations (London, 1996), 199-230, and Winkler, O let us howle some heavy note, 18-62.

33 William Rowley, Thomas Dekker, and John Ford, The Witch of Edmonton (London, 1658; Wing R2097).

34 This is the description accompanying hornpipes printed in John Playford's The Dancing Master, a popular compilation of country dances with outlines of their basic steps first published in 1651. By 1728, long after Playford's death, the book had gone into its eighteenth edition. For a discussion of Playford's manual in relation to the early Stuart masque, see Ravelhofer, The Early Stuart Masque, 41-5.

35 Act 2 of Francis Beaumont and John Fletcher's The Scornful Lady (first performed 1610) offers another example. In attempting to convince his father's steward Savil 
to join the drunken revelry and to dance with his nameless female companions, Young Loveless instructs the fiddlers to 'Strike him a horne-pipe'. Savil replies that he cannot dance 'with' the prodigal's 'Gentlewoman' (Q1, 1616; sTC 1686, D2r-v and Q2, 1625; sтc 1867, C4r-v) or 'Gentlewomen' (Q3, 1630; sTC 1688, C4r-v). Whether the Q1/Q2 or Q3 reading is correct, Savil's response clearly indicates that the hornpipe is not a solo dance.

36 Barnabe Barnes, The Divils Charter (London, 1607; sTC 1466).

37 The Counterfeit Bridegroom: or the Defeated Widow (London, 1677; Wing M1983).

38 Similarly unclear is Thomas Nabbes' 1638 masque A Presentation intended for the Prince his highnesse on his birthday, in which Time transforms three almanac makers into satyrs and instructs them to 'dance a Horne-pipe now', at which point 'They dance: at the end whereof their hornes fall away'; see Thomas Nabbes, Playes, Maskes, Epigrams, Elegies, and Epithalamiums (London, 1639; sTC 18337), F4v. It is difficult to tell whether this hornpipe is performed as a solo step dance, as a mock couple's dance, or in a more stylized manner.

39 The use of a bagpipe at the wedding is a further indication of social rank, as numerous contemporary references testify to the instrument's commonplace association with country folk. In A Nest of Ninnies (London, 1608; sтc 772.7), Robert Armin's witty tale of a Christmas banquet describes how 'Amongst all the pleasures prouided, a Noyse of Minstrells, and a Lincolnshire Bagpipe was prepared: the Minstrels for the great Chamber, the Bagpipe for the Hall: the Minstrels to serue vp the Knights meate, and the Bagpipe for the common dauncing' (B1r). A further example is an entry dated 1656 in Sir Peter Leycester's commonplace book listing 'the severall Kinds of Musicall Instruments now of most Vse in England', in which the bagpipe, along with other wind instruments 'of an inferiour Kind', is described as 'never vsed by any Artists in Musicke; but by the more Rusticall Sorte of People'; quoted (but wrongfully attributed to Philip Leycester) in Frederick J. Furnivall (ed.), Captain Cox, his Ballads and Books (London, 1871), 65-6. For more on the literary and historical treatment of the bagpipe in England, see R.D. Cannon, 'The Bagpipe in Northern England', Folk Music Journal 2.2 (1971), 127-47.

40 John Wallys, 'Our Jockye sale have our Jenny', Thomas Wright (ed.), Songs and Ballads, with Other Short Poems, Chiefly of the Reign of Philip and Mary (London, 1860), 119-24 (no 36), esp. 123-4. The ballad survives in a sixteenth century verse miscellany (British Library ms Ash 48), the various contents of which have been dated by Wright as composed during the reigns of Philip and Mary, with some evidence of works from the early reign of Elizabeth (ii-xi). See also Baskervill, The Elizabethan Jig, 359-60. 
41 Henry Spelman, 'Relation of Virginia', Edward Barber (ed.), Travels and Works of Captain John Smith, 2 vols (Edinburgh, 1910), 1.cxiv. Spelman's account survives in a holograph manuscript, now privately owned, dated approximately 1613.

42 George S. Emmerson, 'The Hornpipe', Folk Music Journal 2.1 (1970), 13; Bratton, 'Dancing a Hornpipe in Fetters', 3; Curti, 'The Hornpipe in the Seventeenth Century', 14; John M. Ward, 'The Lancashire Hornpipe', Lewis Lockwood and Edward Roesner (eds.), Essays in Musicology: A Tribute to Alvin Johnson (Philadelphia, 1990), 143-60.

43 Emmerson, 'The Hornpipe', 13.

44 Ward, 'The Lancashire Hornpipe', 160.

45 Ibid.

46 Curti, 'The Hornpipe in the Seventeenth Century', 14-5. The anonymous Old Meg of Hereford-shire, for a Mayd Marian (London, 1609; sTC 12032) singles out 'Lancashire for Horne-pypes', 'Worcester-shire for Bag-pypes', and 'Hereford-shire for a Morris-daunce' (A4r). In Ben Jonson's 1633 masque, The King's Entertainment at Welbeck, Accidence describes how 'Your Firk-hum-Jerk-hum to a Dance, / Shall fetch the Fiddles out of France; / To wonder at the Horne-pipes, here, / Of Nottingham, and Darbishire'; see Ben Jonson, The Workes (London, 1641; sTC 14754), $2 \mathrm{O} 3 \mathrm{v}$. 